\title{
Subjective Understanding and Individual Interpretation of the Life Value "HEALTH" by the Second-Year Students of Lower Secondary Schools and of the First- and Second-Year Students of Upper Secondary Schools in Slovakia
}

\author{
Slávka Krásna*
}

\begin{abstract}
The article focuses on the value "health", as a component of the value orientation of students of lower secondary schools and upper secondary schools in our country. At the same time, it focuses on the presentation and interpretation of the results of a research conducted on a sample of students of selected schools, which was a part of a more comprehensive research on subjective understanding and individual interpretation of selected life values of lower secondary and upper secondary school students in Slovakia.
\end{abstract}

Key words: values, life values, subjective understanding, individual interpretation, students of lower secondary schools, upper secondary school students.

\section{Introduction}

The values in human life are understood as an interdisciplinary and multidisciplinary concept, and in defining the concept of value orientation we have encountered multiplicity, typical for conceptually rich categories, more in e.g. Hlásna and Dohnanská (2012), Čepelová (2014), Pasternáková (2012, 2013, 2014).

Čepelová (2014) perceives values as an interdisciplinary concept that is explored from different perspectives of science and is used in several scientific disciplines. Philosophy, pedagogy, sociology, ethics, and also psychology deal with this concept, but it is also a commonly used term that can be handled even with no academic and scientific skills.

\footnotetext{
* Slávka Krásna, Dubnica Institute of Technology in Dubnica nad Váhom, Dubnica nad Váhom, Slovakia; krasna @dti.sk
} 
According to Prudký (2004), the concept of values:

- is always related to the meaning of the object attributed to the object by an individual or a group;

- it is the meaning that is essential and that represents the contents of the object for the evaluator;

- the values in the society, in a group, in an institution, in a particular culture and an individual's values, etc. are a relevant factor;

- moral values and the system of values (ethos) are a vital source of motivation and direction of behaviour, they are the source of dissatisfaction/satisfaction, social satisfaction, social cohesion or, on the other side, tension, social exclusion and rejection.

- short- and long-term goals and activities in a group, society, in the state;

- it is particularly important to know one's own value preferences, structure and orientation to be able to define ourselves and our position in the society (Prudký, 2004).

According to another author, values originate from the interaction between the subject and the object of the evaluation. The interaction principle contradicts the a priori nature of values - values exist outside objects and people, they are merely a product of a complex relationship between man and some parts of the (physical or social) environment (Cakirpaloglu, 2009).

Klčovanská (2007, cited in Čepelová, 2014) defines values as the regulators of human behaviour. This definition can be amended to include a view of the regulators of human behaviour. On one hand, our behaviour is regulated by the external environment (external regulators) and depending on this it is regulated by the individual personal (internal regulators). Values in this sense may be also defined as norms that people follow throughout their lives.

Čepelová (2014) in agreement with Sičák (2011) states that values are manifested in a subjective-objective relationship with the evaluation aspect, which in turn affects the behaviour and experience of man. Cognitive and affective aspects of the evaluation are fundamental constructs for the value orientations of a personality.

Hartl and Hartlová (2000, cited in Čepelová, 2014) perceive a value as a criterion, stimulus, standard regulatory element of the activities of an individual or even entire social groups. A value is thus created and differentiated in the socialization process, as a part of social consciousness and it reflects the culture of the society.

The value in a person's life, according to Průcha et al. (2008), is understood as the "subjective degree of importance attributed by an individual to certain things, phenomena, symbols, other people etc."

"The definition of values is not clear at all," Čepelová (2014) states; and, like in many areas of psychology, also in this matter the plurality of opinions prevails. The common denominator in the above definitions is mainly the determining 
character of values, whether in regards to the individual's personality or his conduct; the values are even perceived as a self-regulating element. In summary, it can be concluded that the values constitute one of the defining features of the personality, which means that values are reflected in the personality of an individual, his motivation, needs, activities, behaviour, but also in his temperament.

Further on, Čepelová (2014) states that the theoretical basis of value orientation is defined with a strong emphasis on the search for truth through empirical, critical and rational approach. At this level, people often know what to do, they are able to advise others, but not themselves, because the behaviour of others is easier to evaluate, the problems are more obvious, visible, solvable because they are observed from a certain distance and from a point of view of someone who is only externally affected by the problem. In (any) theory, everything is easily deducible and justifiable, behaviour is precisely defined.

The practical form of value orientation emphasizes the practical values useful in real life and approaches the persistent quality. The theory remains in the background. Sometimes it can be an obstacle, because in order to adhere to the theory we forget to live the life; we are too bound by various rules and principles, adherence to which prevents us from living a spontaneous life.

Finding connections and intersections between the two perceptions is essentially a search for the meaning of human life itself. If we manage to get to the core of the examined issues and to the understanding of the basic parameters and connections as close as possible, we can create some practical recommendations substantiated by relevant theoretical knowledge. The empirical part of the value orientation analysis creates a good basis for the theory and vice versa. Linking theory and practice is a key tool in finding answers to questions and subsequent generalizations (Čepelová, 2014).

Grác (1979) proposes to distinguish the values that are objective and accepted by the society. A person can acquire these values and they become his/her individual, subjective values. The above mentioned author distinguishes the following groups of values:

- unknown values that exist and are valid but they have not yet been acquired;

- identified but unrecognized values - these are the real values that exist in the society, an individual knows them but does not recognize them or identify with them;

- recognized but undesirable values - these are the real preferred values of an individual, however, in some situations they become undesirable (e.g. boldness becomes an undesirable value in case of danger).

- desirable values attract individuals, motivate them to action and they represent the goals to achieve.

Cakirpaloglu (2009) states 22 categories of value classification:

1. Category of the carrier of values - according to this category the author divides the values into individual, group and universal values; 
2. Category of the origin of the values - values are divided by origin into individual and universal values;

3. Category of the values' function and position - here we can divide the values into values as a means and values as a goal;

4. Category of generality - according to the degree of generality, the author distinguishes between specific and general value preferences;

5. Category of the relation of values to the human nature and to the nature of animals;

6. Category of the hierarchic position of the value - values are categorized according to Maslow's hierarchy of needs;

7. Category of value substantiality - here the author distinguishes between two types of values:

- expected values - normative standards of conduct,

- values oriented on the realization of existence;

8. Category of the value content - according to the content, the above mentioned author divides the values into the following groups:

- normative values

- values emphasizing the individual and social desirability,

- preferences affecting behaviour.

9. Category of the human needs role - according to this, the author distinguishes:

- values adapting to new and changing conditions, the so-called adapting values;

- values focusing on the defence of ego, called defence values ;

- values of growth and learning - self-fulfilment, learning;

10. Category of the direction of preferences - the author distinguishes the value areas by the type of goodness;

11. Category of the degree of consciousness - according to this the values can be broken down into:

- conscious - occur in adults and mentally healthy persons,

- unconscious - found in the behaviour of children, immature individuals and pathological cases;

12. Category of the values' manifestation intensity:

- relating to the external, surface and internal human characteristics explicit values or implicit values,

- values according to the time factor - actual, potential,

- socially oriented values

13. Category of the approach and attitude to the reality;

14. Category of time perspective - past, present, future;

15. Category of the degree of inference - inductive approach, deductive approach;

16. Category of effect modality:

- positive and negative values, 
- progressive and regressive values

- potential and actual values,

17. Category of the extent of embededness - the author distinguishes:

- external and internal values,

- true and authentic values;

18. Category of the distance of values from the person:

- specific values - represent emotional attachment to close and familiar contents, matters and objects;

- abstract values associated with distant objects, objectives;

19. Category of values' intensity is focused on determining the value intensity;

20. Category of the value location - objective values (external behaviour, external goals ...) and subjective values (intrinsic properties, internal goals...);

21. Category of the means of operationalizing the value, i.e. the position and function of preferences in the research process, where the values may represent an independent or dependent variable;

22. Category of the size of preferences determines and classifies the values based on a predetermined rate, size - quantitative classification of values, while something may have a higher, something a lower value within the same category.

As Vacek (2013) notes, everyone has their own system of values, which guides their actions and thinking. It is not important whether one is aware of his hierarchy of values or if his actions are rather intuitive. The more comprehensive a value system is, the more connected it is to the overall personality of an individual, and the more significant influence it may have on the behaviour of an individual. The system of values is an important indicator of the personality orientation and it significantly affects their motivation and self-regulation.

According to Nákonečný (2009), the processes of formation and shaping of value orientation are influenced by exogenous and endogenous factors in human life and - as follows from the analysis of several authors' work - value orientation is a relatively stable category of life, having also a certain degree of rational justification. At the same time, it is a category formed and shaped in interaction with other people which significantly influences the life of an individual in the society - depending whether and to what extent he/she accepts the values declared by the society as socially desirable and adopts them for his own."

According to Göbelová (2008), value orientation is a hierarchical set of values adopted by individuals, groups, communities, and it represents a continuous, relatively stable system of values, which in turn regulate and direct the behaviour of an individual or group of people. Individual value orientation consists of a system of attitudes, interests, preferences and tendencies to act and behave in a certain way. The author further notes that the value orientation of a person, therefore, is one of the most important parts of the internal structure of 
our personality because it reflects our experience, and based on this it allows us to differentiate the (in)correct, irrelevant/relevant; it allows us to assume a standpoint in our life.

The development of young people's value system, according to Kraus (2006), is not yet complete, because young people create their value orientation in confrontation with diverse life situations and other endogenous or exogenous influences. According to the author, today's youth (girls more than boys) are more prone to commercialization - approximating the model of global youth in reflection of the world's globalization. Young people at present do not protest against the consumer society of adults, on the contrary, some research shows that the value system of youth more or less aligns with the average values of the entire population, the main preferred values being friendship, leisure and travel.

In our opinion the value orientation is affected - among other factors - by the often omitted context of a group of people belonging to the same generation, which, according to several authors (Krásna, 2013), manifests common characteristics significantly different (not only from the sociological point of view) from the previous or the following generation (more details to follow).

\section{Methodology and Research Methods}

After the $3^{\text {rd }}$ grade students of lower secondary schools (more Hlásna Dohnanská, 2012), we have focused the most recent survey of subjective understanding and individual interpretation of selected life values on the $1^{\text {st }}$ and $2^{\text {nd }}$ year students of upper secondary school. Currently known research of value orientation of lower secondary and upper secondary school students in Slovakia was performed mainly by means of quantitative methods in several age groups. In case the respondents were to arrange the life values previously selected by researchers, health as a life value was usually in the first place or at least one of the first places (e.g. Koláŕ, 1997; Sak, 2000 and 2004; Klčovanská, 2001; Šamanová, 2004). The same results were recorded in supervising the graduation thesis and other final papers of our students (Nerádová 2007; Gajdúšek 2007; Pal'uš 2007; Kubovičová 2009; Samko, 2011; etc.). We would like to expand these existing views for the exploration of subjective understanding and individual interpretation of the selected life values of students.

By means of a simple questionnaire we have created, we focused on the exploration of subjective understanding and individual interpretation of the selected life values of lower secondary and upper secondary school students; however, we are going to use possible methods of quantitative and also qualitative evaluation of the obtained data.

We formulated the following research objectives:

1. to determine the subjective understanding of selected life values of the $3^{\text {rd }}$ and $5^{\text {th }}$ grade students of lower secondary schools and the $2^{\text {nd }}$ grade students 
of upper secondary schools and to interpret it in relation to variables: students' gender and school location;

2. to identify the individual interpretation of the selected life values of the $3^{\text {rd }}$ and $5^{\text {th }}$ grade students of lower secondary schools and the $2^{\text {nd }}$ grade students of upper secondary schools and to interpret it in relation to variables: students' gender and school location.

We formulated the following research questions:

- What is the subjective understanding of selected life values of students of selected grades of lower secondary and upper secondary schools?

- What is the individual interpretation of selected life values of life of students of selected grades of lower secondary and upper secondary schools?

- What is the relationship between the subjective understanding of selected life values of students of selected grades of lower secondary and upper secondary schools and the students' gender?

- What is the relationship between the subjective understanding of selected life values of students of selected grades of lower secondary and upper secondary schools and the school location?

- What is the relationship between the individual interpretation of selected life values of students of selected grades of lower secondary and upper secondary schools and students' gender?

- What is the relationship between the individual interpretation of selected life values of students of selected grades of lower secondary and upper secondary schools and the school location?

We set the following research variables: selected life values, gender and school location.

We established the following research sample for the whole conducted research: the research sample will consist of the $3^{\text {rd }}$ and $5^{\text {th }}$ grade students of lower secondary schools and the $2^{\text {nd }}$ grade students of upper secondary schools, who will be divided by gender and school location during the evaluation and interpretation of the results. Sample will only consist of the students of fully organized (where at least one class of each grade is open) state schools in Bratislava and in smaller towns in Slovakia, the condition being that the school is not in a village and it is not a non-fully organized school (where one or more grades are not open due to insufficient number of students) or school with combination-class or one-class system. The sample selection is not strictly random, but given by the willingness of principals, representatives of schools and school teachers to allow this kind of research at their school and classroom. (Non)fulfillment of the objectives and answers to the research questions can be resolved only after completing data collection, the obtained data will be evaluated and subsequently interpreted. Meanwhile, we can only describe the partial findings. 
The first research survey was carried out in the $2^{\text {nd }}$ semester of 2011/2012 in questionnaires for $3^{\text {rd }}$ grade students of lower secondary schools in different localities of Slovakia (Hlásna and Dohnanská, 2012).

The subsequent research survey was conducted in the first semester of 2013/2014 via anonymous questionnaires. 288 questionnaires were distributed to schools, the return rate being $100 \%$; however, 7 questionnaires were not counted into the evaluation since they were not filled-in or they were filled with vulgarisms. We can categorize the sample of the surveyed respondents by:

1. Gender - Questionnaires were filled-in by 281 students: 133 girls, which constitutes $48.6 \%$ and 148 boys, which constitutes $51.4 \%$ of the sample of respondents. All respondents filled in the gender data.

2. Locality - Questionnaires were distributed to five upper secondary vocational schools in the Trenčín, Nitra, Banská Bystrica and Žilina region (Secondary Technical School of Civil Engineering Žilina, Business Academy Zlaté Moravce, Secondary Vocational School Tisovec, Secondary Technical School of Civil Engineering Trenčín, Combined Secondary School Partizánske). Questionnaires were completed by 281 students, which represents $97.6 \%$ of the sample. All questionnaires contained the necessary identification data. (Data from the students of Bratislava schools have not yet been evaluated by the date of submission of this paper).

Since the subsequent data collection for the purposes of our research was focused on the $1^{\text {st }}$ and $2^{\text {nd }}$ grade students of upper secondary vocational schools, we decided to use a simple anonymous questionnaire "Subjective understanding and individual interpretation of selected life values of upper secondary school students".

"The purpose of this anonymous questionnaire is to find out how the upper secondary school students understand certain life values, how they interpret them, what the values mean to them, what values are included there... Your class was chosen from many upper secondary schools throughout Slovakia, because you are able to adequately express your own opinion. Please write a few sentences about the terms below, in which you explain what it is, what is the meaning of that term ... HEALTH, HAPPINESS, FRIENDSHIP, LOVE and FAMILY." Before the end of the questionnaire we asked them the following question and provided appropriate space for their comments: "Which of your requirements, dreams, life goals must be met to make you consider yourself RICH in some area of your life?" At the end of the questionnaire respondents were asked to indicate the year (1 23 4), gender (girl - boy) and location of the school (Bratislava - outside Bratislava); after this we thanked them for completing the questionnaire.

\section{Findings}

The evaluation of the questionnaires distributed to the 1st and 2nd grade students of upper secondary vocational schools was performed in the first semester of 
2013/2014 through questionnaires for the $1^{\text {st }}$ and $2^{\text {nd }}$ grade students of upper secondary vocational schools in various localities of Slovakia. 281 students expressed their opinion on the examined life value - HEALTH.

Table 1 The most common responses of students of upper secondary schools outside Bratislava regarding the item HEALTH

\begin{tabular}{|l|l|l|l|l|l|}
\hline & Girls & Number & & Boys & Number \\
\hline I. & $\begin{array}{l}\text { Health is the most } \\
\text { important }\end{array}$ & 86 & I. & $\begin{array}{l}\text { Health is the most } \\
\text { important }\end{array}$ & 91 \\
\hline II. & Not being sick & 20 & II. & Not being sick & 28 \\
\hline III. & $\begin{array}{l}\text { Physical and mental } \\
\text { health }\end{array}$ & 15 & III. & $\begin{array}{l}\text { It should be protected } \\
\text { and cherished }\end{array}$ & 11 \\
\hline IV. & $\begin{array}{l}\text { It should be } \\
\text { protected } \\
\text { cherished and }\end{array}$ & 7 & IV. & $\begin{array}{l}\text { Physical and mental } \\
\text { health }\end{array}$ & 9 \\
\hline V. & Quite important & 5 & V. & $\begin{array}{l}\text { Healthy lifestyle, diet, } \\
\text { environment }\end{array}$ & 6 \\
\hline
\end{tabular}

Source: own research

From the interesting answers of respondents in this group we have selected:

\section{Girls of selected grades of upper secondary vocational schools further stated:}

"Health is something you cannot buy. It's the most important thing a few people appreciate, only a few people have health. I personally try to do as much as possible for my health." (girl/school in Žilina)

"It is an irreplaceable part of our lives that we often do not appreciate. We only understand the value of health once we get sick." (girl/school in Tisovec)

"We only have one health, so we should treasure it. Not everyone is healthy. Those who are healthy do not appreciate it and those who would like to have it, cannot have it." (girl/school in Partizánske)

"Health is divided into physical and mental. Physical health depends on lifestyle. Which means the diet, sports activities - everyone needs appropriate amount of physical activity; and, what is a major problem at present, whether the person smokes and drinks alcohol. Mental health - in my opinion, it cannot be defined. Everyone has a different life and develops differently and everyone has different things that are natural for them." (girl/school in Trenčín) 
The boys from selected grades of upper secondary vocational schools further stated:

"Health means to me the opportunity to go anywhere and do anything without restrictions due to pain or illness." (boy/school in Žilina)

"Living in a healthy environment. Unfortunately it's no longer possible." (boy/school in Tisovec)

"For me, health is just a word, I do not care if I die today or tomorrow." (boy/school in Partizánske)

"Health means to be free of the addictions of the modern world: coffee, cigarettes, drugs, alcohol, gluttony. Devoting more time to our external and internal (mind) wellbeing and less time to the "thieves of time" such as TV, PC games." (boy/school in Trenčín)

"Healthy diet and healthy living. No smoking, drinking or drugs." (boy/school in Trenčín)

"Health should be valued, because not everyone is healthy. When people are healthy, everything is easier." (boy/school in Zlaté Moravce)

Tab. 3 The most common responses of girls of the $3^{\text {rd }}$ grade of lower secondary schools and selected grades of upper secondary vocational schools outside Bratislava regarding the item HEALTH

\begin{tabular}{|c|c|c|c|c|c|}
\hline & $\begin{array}{l}\text { Girls, } 3^{\text {rd }} \text { grade of lower } \\
\text { secondary schools }\end{array}$ & & & $\begin{array}{l}\text { Girls (upper secondary } \\
\text { vocational schools) }\end{array}$ & \\
\hline I. & $\begin{array}{l}\text { Health is important/the } \\
\text { most important }\end{array}$ & 39 & I. & $\begin{array}{l}\text { Health is the most } \\
\text { important }\end{array}$ & 86 \\
\hline II. & Life without illness & 22 & II. & Not being sick & 20 \\
\hline III. & $\begin{array}{l}\text { Physical health } \\
\text { Mental health }\end{array}$ & $\begin{array}{l}18 \\
18\end{array}$ & III. & $\begin{array}{l}\text { Physical and mental } \\
\text { health }\end{array}$ & 15 \\
\hline IV. & Health is happiness & 13 & IV. & $\begin{array}{l}\text { It should be protected and } \\
\text { cherished }\end{array}$ & 7 \\
\hline V. & $\begin{array}{l}\text { Health can not be bought } \\
\text { Health should be valued } \\
\text { Health should be protected }\end{array}$ & $\begin{array}{l}9 \\
9 \\
9\end{array}$ & V. & Quite important & 5 \\
\hline
\end{tabular}

Source: own research

Our sample of girls demonstrated that also the female students at lower secondary and upper secondary schools consider health to be the most important value; health is defined as the life without illness by most of our female respondents. In both age groups the concept of physical and mental health is in 
the third place in terms of the frequency of occurrence. Younger girls in our sample perceive health also as happiness and as a value which "cannot be bought". Group of younger and older girls subjectively perceives and interprets health as a value that should be protected and cherished.

Tab. 4 The most common responses of boys of $3^{\text {rd }}$ grade of lower secondary schools and selected grades of upper secondary vocational schools outside Bratislava regarding the item HEALTH

\begin{tabular}{|c|c|c|c|c|c|}
\hline & $\begin{array}{l}\text { Boys - lower secondary } \\
\text { schools }\end{array}$ & & & $\begin{array}{l}\text { Boys - upper secondary } \\
\text { vocational schools }\end{array}$ & \\
\hline I. & $\begin{array}{l}\text { Health is important/the } \\
\text { most important }\end{array}$ & 19 & I. & $\begin{array}{l}\text { Health is the most } \\
\text { important }\end{array}$ & 91 \\
\hline II. & Life without illness & 18 & II. & Not being sick & 28 \\
\hline III. & Health is a condition & 9 & III. & $\begin{array}{l}\text { It should be protected and } \\
\text { cherished }\end{array}$ & 11 \\
\hline IV. & $\begin{array}{l}\text { When I feel well / When I } \\
\text { feel good }\end{array}$ & 6 & IV. & $\begin{array}{l}\begin{array}{l}\text { Physical and mental } \\
\text { health }\end{array} \\
\text { lal }\end{array}$ & 9 \\
\hline V. & $\begin{array}{l}\text { Physical health } \\
\text { Mental health } \\
\text { To value the health }\end{array}$ & $\begin{array}{l}5 \\
5 \\
5\end{array}$ & V. & $\begin{array}{l}\text { Healthy lifestyle, diet, } \\
\text { environment }\end{array}$ & 6 \\
\hline
\end{tabular}

Source: own research

Our sample of boys showed that lower secondary and upper secondary school students perceive health as the most important; health was defined as life without illness by most our respondents. Younger students of our sample state that health is a condition and at the same time that health is when you feel well. In both age groups the concept of health in the context of physical and mental health occurs as well. The older boys perceive health also in terms of a healthy lifestyle and diet; this viewpoint does not occur in the group of younger students. The younger and older students in our sample concur on subjective perception and individual interpretation of health as a value that should be protected and cherished.

Our respondents also state that they do not do things that would endanger their health and do not even want to try; they also expressed a wish for all people to be healthy. They deem it important to help the sick. To other respondents health means being without harm or injury, feeling good, having good immunity, a lot of minerals, not having to see a doctor; health is not having to wear glasses, being able to do anything, living without pain, having a good diet, stress-free life, being able to have fun and do sports, having no disability (eg. sick brain), crutches, wheelchair, no physical or mental impairment, no complicated illness, enjoying life; health means life without cancer and depression; they have associated the life in poor conditions with health deterioration. They further 
stated that their future life development depends on health and that health can be destroyed by alcohol, cigarettes, drugs. It has also been shown that as the students get older they feel the need to cherish and protect their health for example by healthy lifestyle. In both age groups, the concept of health in the context of physical and mental health occurs as well.

\section{Discussion and conclusions}

Based on the analysis of the sample responses, we can conclude that the majority of the $1^{\text {st }}$ and $2^{\text {nd }}$ grade students of upper secondary vocational schools in the Trenčín, Nitra, Banská Bystrica and Zilina regions subjectively perceive the concept of health as the most important value. In the survey sample of boys this was indicated by $61.5 \%$ and in the sample of girls by $64.7 \%$ of respondents. Only three boys stated that health is not important, none of the girls in our sample indicated this. $15 \%$ of girls and $19 \%$ of boys described health as the absence of illness. In $11.2 \%$ of the girls' responses and in $6 \%$ of the boys' responses health is perceived as the unity of physical and mental health. A common feature in most of the completed questionnaires was the emphasis on the need to protect and promote health - the need to protect and value the health was emphasized in the responses of 5.3\% of girls and $7.5 \%$ of boys. Several respondents declared the concept of health as a link between health and a healthy lifestyle. As the acquired findings show, the girls and boys in our sample do not take health for granted and they point out the limitations resulting from health complications or difficulties.

Only three respondents complained about their health. It was also revealed that some respondents are sensitive to the health condition of their family members (my grandmother is sick too, she takes a lot of medicine...) or persons with whom they are in closer contact (my friend lost her mother - she died of smokefilled lungs...). This respondent's statement is also affecting her views on our society: "So the cigarettes shouldn't even be produced"...

Our respondents expressed subjective perception and individual interpretation of the concept of health as the highest value associated with the trouble-free way of life - going to school, performing routine activities; also with a healthy lifestyle, healthy diet, healthy food, disease prevention, medication, concerning their own health and as well as the health of their close ones; with the living conditions; they also demonstrated awareness that smoking, alcohol, drugs, etc. seriously harm human health.

There were no forms of subjective perception and individual interpretations of the concept of health related to preventive health check ups, to maintaining good hygiene and to health in terms of the whole population, for example in connection with countries with health risks, health as a medical term, health in the context of health insurance, vaccination, healthy work conditions, health requirements to perform particular work, in the relation to pandemics, chronic 
diseases, diagnostics or animals' health. It is obvious that these components of daily life do not resonate with the lower secondary or upper secondary school students, they do not have experience or direct contact with them. However, we suppose that if we had conducted our survey at the time of publishing of this paper when the Ebola disease is a widely discussed topic, this would have been reflected in the subjective perception and individual interpretation.

The questionnaires handed in by the $3^{\text {rd }}$ grade students of lower secondary schools, as well we the students of upper secondary schools were often difficult to read and contained a lot of grammar and spelling mistakes. Some of the questionnaires could not be included into the research evaluation due to the use of coarse language; however, this was not the case of the $3^{\text {rd }}$ grade students of lower secondary schools. So far we can conclude that the students of the selected upper secondary vocational schools usually perceive health similarly to the definition of the World Health Organization, which defines health as "the state of complete physical, mental and social well-being while preserving the ability of the body to adapt to the changing conditions of life." However, this view has certain distinctive individual characteristics, as was expected.

When observing the common characteristics in the responses we have evaluated so far, we can conclude that the girls filled in the questionnaires more completely and the boys wrote less and more simply. Although it was the contents of the responses, not their form, what was important to us, it is obvious that most students' responses were rather unreadable and contained a lot of grammar and stylistic mistakes.

From the above results of research and the results of the research processed so far, we can generate some forms of values in terms of subjective understanding and individual interpretation of selected life values by students:

a) global values and partial values - Global values are based on values socially preferred in our society, based on global values of our planet and as such they give rise to the partial values of the individual (or society of people) which are identified by the individual. On the other hand, each of the preferred values of the individual is based on the globally recognized values (e.g. moral code, law, religious principle etc.) which are then analyzed and modified, accepted, preferred, recognized and internalized by the individual or society at various stages of human life and development ("Living in a healthy environment").

b) universal values and unique values - Universal values are based on the "written" and "unwritten" rules and standards of the world, of the society or a particular social group in a form beneficial for the mankind. Unique values are created in a unique situation for an individual, couple or group, and they are based on the uniqueness, specificity of a particular situation or person ("Health means to me the opportunity to go anywhere and do anything without restrictions due to pain or disease"). 
c) values proximal in time and values distant in time - Values proximal in time are identified by an individual based on the values distant in time accepted in the particular society and perceived individually by individuals and social groups. And vice versa, the foundation of the values distant in time is created in the positions proximal in time which can be delimited in short-term, medium-term and long-term ("Health affects the future development of our life");

d) short-term and long-term values are often subjectively perceived and interpreted individually in the overall value system of the individual within the society - long-term values consist of many short-term values, and after the "priority" of a short-term values ceases, another short-term value emerges with the perspective of being included in a long-term value etc. ("Health is always the most important in human life");

e) autonomous and heteronomous values are based on the fundamental difference in their origin - an individual uncovers the autonomous values inside himself, while the heteronomous values are offered to him from "outside". Resolving the (in)consistency levels between them is the focal point of the individual value system in confrontation with the preferred values of the community, social group, society ("It is insane that young children get hammered.");

f) individual and group values in the process of their creation and subsequent internalization (if that is the case) are influenced by the reality of life - individual values are focused on the individual and are mostly autonomous; group values are preferred in a larger social group ("I am happy when my friends are healthy too.");

g) values at the informative and formative level - The values at the informative level are based on the cognitive aspects of human life and specific knowledge, facts, information; the values at the formative level are based on the internalization of values, their direct impact on the system of values of a particular individual, his views, experience, degree of his personality development, mental ability, axiological concepts of the individual etc. ("People who live in poor conditions tend to get sick.");

h) adaptation and anticipatory values - the adaptation values are reflected in the current life situation, in the presence of adaptation to the current life conditions of an individual's life within a society; the anticipatory values relate to a possible situation in the near and more distant future, considering the future needs of a well-rounded active life of an individual, social group or society ("Health means being free of the addictions of the modern world: coffee, cigarettes, drugs, alcohol, gluttony. Devoting more time to our external and internal (mind) wellbeing and less time to the "thieves of time" such as TV, PC games."

i) traditional values and innovative value - From the content point of view, traditional values represent the stable norms of a specific social group or 
society and represent their unchanging value "setting"; on the other hand, the innovative values reflect the current needs of every society. The ideal case is when the traditionally set "proven" values are preserved but adapted to the current innovative components of values. ("Health means a lot to me. I do not do things that would jeopardize it nor do I want to try.");

j) standardized values and existential values - The essence of the standardized values is their worldwide recognition and declaration as a standard of globally and universally preferred and applied values and preferences; existential values that are often in conflict with them result from the current situation, when a person is struggling for survival (healthy food vs poverty induced diet, consumation of unsuitable food, for example food from garbage, etc.).

k) socially desirable values and socially undesirable values - socially desirable values are in accordance with social or group norms, and vice versa, socially undesirable values are in conflict, in contrast with them. There is a possibility of including the undesirable values into the value system of an individual or group ("For me, health is just a word, I do not care if I die today or tomorrow.");

1) progressive values - regressive values - Progressive values are advancing, ongoing, developing in a positive way, these are the values that provide the possibility of human progress, it can be assumed that these values will also be relevant in the following years of the life of an individual or a group. Regressive values are the values that do not provide the opportunity to move forward, it can be assumed that these values are not going to be relevant in the following years of a person's life and their preference would mean "a step back" to the lower level of the value system, possibly dysfunctional in terms of the future world or causing difficulties in the future life ("I'll start taking care of my health only when I get older.");

m) priority value - secondary values - priority, preferred values come first in the value system of the society or individual and secondary values are those which are still important to an individual or society, but they are secondary to the first group of priority values ("The human life and health is the most important, other things also important, but they are secondary.");

n) stable form of values - labile form of values - stable form means deeply internalized values, unchanging, steady, balanced values in the life of an individual or recognized by the society in the long term; labile form of values is presented by its shallowness, lack of internalization, relatively rapid volatility ("Health is an indispensable part of our lives that we often do not appreciate. We only understand the value of health once we get sick.")

The collected partial results of the survey on the subjective perception and individual interpretation of selected individual life values of the $3^{\text {rd }}$ grade 
students of primary schools and upper secondary schools in Slovakia are the respective sample of $1^{\text {st }}$ and $2^{\text {nd }}$ grade students of upper secondary vocational schools will become a part of a comprehensive survey of a wider sample of the $3^{\text {rd }}$ and $5^{\text {th }}$ grade students of primary schools and $2^{\text {nd }}$ grade students of upper secondary schools in fully organized state schools in selected Slovak towns and they will form a part of a broader interpretation of the results. The sample of students is experiencing "its" adolescence and the well-known typical features of this developmental period will naturally be taken into consideration during the interpretation of these results (e.g. Tamášová and Geršicová, 2013). At the same time, we realize that when interpreting the results, it is necessary to take into account the fact that each generation, according to sociologists, has its own specific way of life and, consequently, its own specific requirements. This is most visible in direct comparison with the previous generation. Thirty, twenty or even ten years ago, the visions of how the world would be like in 2010 were completely different from the current reality. The rise of personal computers, mobile phones and social networks surpassed the most daring predictions. Currently, there is a generation being formed and growing up, which has been in touch with these technologies since the early childhood. These are young people who perceive communication, reality, friendships, information in a completely different way than people in their thirties (The Generation $\mathrm{Z}$ is coming). Several authors agree that the behaviour, values and attitudes of the "Millennium Children" differ significantly from the previous generation in response to technological and economic impacts of the internet. However, another group of experts say that the characeristics vary by region, depending on the social and economic conditions in which they live (The Generation $\mathrm{Z}$ is coming). According to Saviit, the Generation $\mathrm{Z}$ is the most self-assertive generation in modern history (Sedlaková, 2012) - instead of waiting for the information to be filtered by the previous generations, it dictates the trends - often even before completing the primary school. Social networking overcomes all the barriers in communication... - everyone able to write can share their knowledge and experience - and sharing the knowledge is essential to the Generation Z. The above findings, in our opinion, show a different view on the way of building and sharing values among young people, who are the target group of the research.

"Health is the only value recognized by all ..." (Latin proverb)

\section{References}

CAKIRPALOGLU, P. Psychologie hodnot. Olomouc: Vydavatelství Univerzity Palackého, 2009.

ČEPELOVÁ, S. Edukačné hladisko hodnôt a hodnotovej orientácie. Jazykovedné, literárnovedné a didaktické kolokvium XXIV. Bratislava: ZF LINGUA, 2014. 
GAJDÚŠEK, V. Hodnotová orientácia stredoškolskej mládeže vo vybraných školách v Bratislave (Bachelor's thesis). Bratislava: PdF UK, 2007.

GURIČAN, R. Subjektivne chápanie a individuálna interpretácia životnej hodnoty zdravie žiakmi vybraných stredných odborných škôl SR (Bachelor's thesis). Dubnica nad Váhom: DTI, 2014.

GÖBELOVÁ, T. Hodnotová výchova v pedagogické praxi. Ostrava: Ostravská univerzita, 2008.

HLÁSNA, S. and DOHNANSKÁ, M. Subjektívne chápanie a individuálna interpretácia zvolených životných hodnôt žiakov 7. ročníka II. stupňa vybraných základných škôl v SR. Acta humanica, 9, 2012, 2a, pp. 211-218.

KLČOVANSKÁ, E. Význam hodnôt vo vzt’ahu k štruktúre osobnosti. Človek $\mathrm{v}$ centre psychologického skúmania a starostlivosti. Acta Psychologica Tyrnaviensia, 2001, 5, pp. 23-32.

KOLÁR̆, P. Hodnotová orientace a využití volného času dětí a mládeže: informační studie č. 5. 091. Parlamentní institut Parlamentu ČR [on-line]. 1997. [viewed 17 October 2014]. Available from: $<$ http://www.psp.cz/kps/pi/PRACE/PI-5-091.DOC>

KUBOVIČOVÁ, A. Subjektívny pohlad na hodnotový systém adolescentov (Bachelor's thesis). Bratislava: PdF UK, 2009.

KRÁSNA, S. Výchova a vzdelávania a generácie. Jazykovedné, literárnovedné a didaktické kolokvium XXII. Bratislava: ZF LINGUA, 2013.

NÁKONEČNÝ, M. Psychologie osobnosti. Praha: Academia, 2009.

Prichádza generácia Z. [on-line]. 2012. [viewed 17 April 2012]. Available from: $<$ http://www.buducnostinternetu.sk/temy/clanky/generacia-z.php $>$

NERÁDOVÁ, Z. Hodnotová orientácia stredoškolskej mládeže (Bachelor's thesis). Bratislava: PdF UK, 2007.

PALUŠ, L'. Hodnotová orientácia stredoškolskej mládeže (Bachelor's thesis). Bratislava: PdF UK, 2007.

PASTERNÁKOVÁ, L. Komparácia úrovne hodnotovej orientácie žiakov ZŠ na Slovensku a v Česku. Dilemata sociálni pedagogiky v postmoderním světě. Brno: Institut mezioborových studií Brno, 2012.

PASTERNÁKOVÁ, L. Vznik hodnôt u detí predškolského veku. Integrowanie dydaktyczno-wychowaczych $w$ edukacji elementarnej. Katowice: Uniwersytet Slaski w Katowicach Wydzial Pedagogiki i Psychologii, 2013.

PASTERNÁKOVÁ, L. Hodnotová preferencia žiakov staršieho školského veku zo Slovenska a Česka. Lifelong Learning - celoživotní vzdělávání. [on-line]. 2014. [viewed 17 October 2014]. Available from: <http://www.vychovavzdelavani.cz/l11401/studie_pasternakova>

PRUDKÝ, L. Hodnoty a normy $v$ české společnosti. Praha: Akademické nakladatelství Cerm, 2004.

PRŮCHA, J., WALTEROVÁ, E. and MAREŠ, J. Pedagogický slovník. Praha: Portál, 2008. 
SAK, P. Proměny české mládeže: česká mláděz v pohledu sociologických výzkumu. Praha: Petrklíč, 2000.

SAK, P. Mládež na křižovatce: sociologická analýza postavení mládeže ve společnosti a jeji úlohy v procesech evropeizace a informatizace. Praha: Svoboda Servis, 2004.

SAMKO, L. Hodnotová orientácia stredoškolskej mládeže na odborných a technicky zameraných školách. Bratislava: MTF UIPH STU, 2011.

SEDLÁKOVÁ, K. Generácia Z - nastupuje najbystrejšia generácia. [on-line]. 2012. [viewed 17 October 2014]. Available from: $<$ http://feminity.zoznam.sk/c/879180/generacia-z-nastupuje-najbystrejsiageneracia>

ŠAMANOVÁ, G. Hodnotové orientace. Naše společnost: Sociologický ústav AV $\check{C} R$. [online]. 2004. [viewed 30 September 2013]. Available from: $<$ http://www.cvvm.cas.cz/index.php?lang=0\&disp=zpravy\&r=1\&shw=100371> TAMÁŠOVÁ, V. and GERŠICOVÁ, Z. Chaos v hodnotách alebo podpora rodičov a učitel'ov pri vštepovaní a prijímaní hodnôt stredoškolskou mládežou. JABLONSKÝ, T. and MATÚŠOVÁ, S. Učitel' a hodnoty. Európske hodnoty a kultúrne dedičstvo - výzva pre vzdelávanie. Ružomberok: VERBUM vydavatel'stvo Katolíckej univerzity, 2013. pp. 269-285.

TWENGE, J. Generation Me. New York: NY Free Press, 2006. 